\title{
電離層プラズマ一高電圧ソーラーパネル間 相互作用の数值解析*
}

田原 弘一**. 高木 一樹**. 安井 利明**. 吉川 孝雄**

（受理1996年11月29日，掲載決定1997年 3 月 1 日）

Numerical Analysis of Interactions of High Voltage

Solar Panels with the Ionospheric Plasma

Hirokazu TAHARA, Kazuki TAKAGI, Toshiaki YASUI and Takao YOSHIKAWA

(Faculty of Engineering Science, Osaka University, 1-3, Machikaneyama, Toyonaka, Osaka)

(Received November 29, 1996, Accepted March 1, 1997)

\section{1. まえがき}

近年の宇宙開発の進展に伴い, 高度 $1000 \mathrm{~km}$ 以下の低 地球軌道 (Low Earth Orbit: LEO) 上に拈いて, 宇宙 ステーションに代表される大型大電力宇宙構造物を建設 することが計画されている．これら宇宙構造物では大電 力を供給するために, 出力電圧が高いソーラーパネルを 利用することが検討されている. しかしこの高電圧ソー ラーパネルは電離層プラズマで取り囲まれるため, 帯電 放電, 材料劣化, イオンドラッグなどの様々な現象を引 き起こし, 将来これらが深刻な問題になることが懸念さ れている1-5).これは Fig. 1 の左側のソーラーパネルに 示すように, 電離層プラズマに曝されたパネル導電部 (パネルの表に張られた, 多数の太陽電池素子を接続す るコネクタ）の電位がそのプラズマ電位に対して大きく 負になることに起因する。

そこで本研究では, 電離層プラズマと高電圧ソーラー パネルとの干渉現象を調べるために, 高電圧ソーラーパ ネル周りの 3 次元プラズマ粒子運動を数値解析し, イオ ンシース形状, 挙動を明らかにすると共に, そのイオン 運動について検討した。

* 平成 8 年 10 月 30 日 第 37 回真空汇関する連合講演会で講演

** 大阪大学基䃈工学部（广560 大阪府豊中市待兼山町1-3）

\section{2. 計算モデルと解析方法}

計算を行らにあたり，3 次元空間内を単純な長方形の 板状の高電圧ソーラーパネルが高度 $500 \mathrm{~km}$ の軌道上を $7.6 \mathrm{~km} / \mathrm{s}$ の軌道速度で飛行するモデルを考えた.ソー ラーパネルの長さと幅はそれぞれ $5 \mathrm{~m}$ と $1 \mathrm{~m}$, 厚さは零 とし, 一方の面を導電面, も5一方の面を絶縁面とす る。また高度 $500 \mathrm{~km}$ の酸素プラズマの密度は $5 \times 10^{5}$ $\mathrm{cm}^{-3}$ であり, イオンは無衝突運動をし, 電子はボルッ マン分布に従らとする.すなわち, ソーラーパネルの電 位はプラズマ電位に対して深く負に沈みその周りにはイ オンシースが発達するので，イオンについてのみ粒子の 追跡を行った.こうして，次の計算上の仮定を行う．1） 電離層をプラズマとみなす．2)電子の分布はボルッマン 分布 (電子温度 $0.2 \mathrm{eV}$ ) とする. 3) イオン温度は零とす る.4)イオンは無衝突である.5)地磁気の影響は無視す る. 6)イオンがソーラーパネルに衝突する時, 中性化さ れる。

基礎方程式は次にポアソンの方程式, イオンの運動方 程式, 電子に関するボルッマン平衡の式で構成される.

$$
\begin{aligned}
& \nabla^{2} V=-\frac{e}{\varepsilon}\left(N_{i}-N_{e}\right) \\
& M \frac{d v}{d t}=-e \nabla V
\end{aligned}
$$




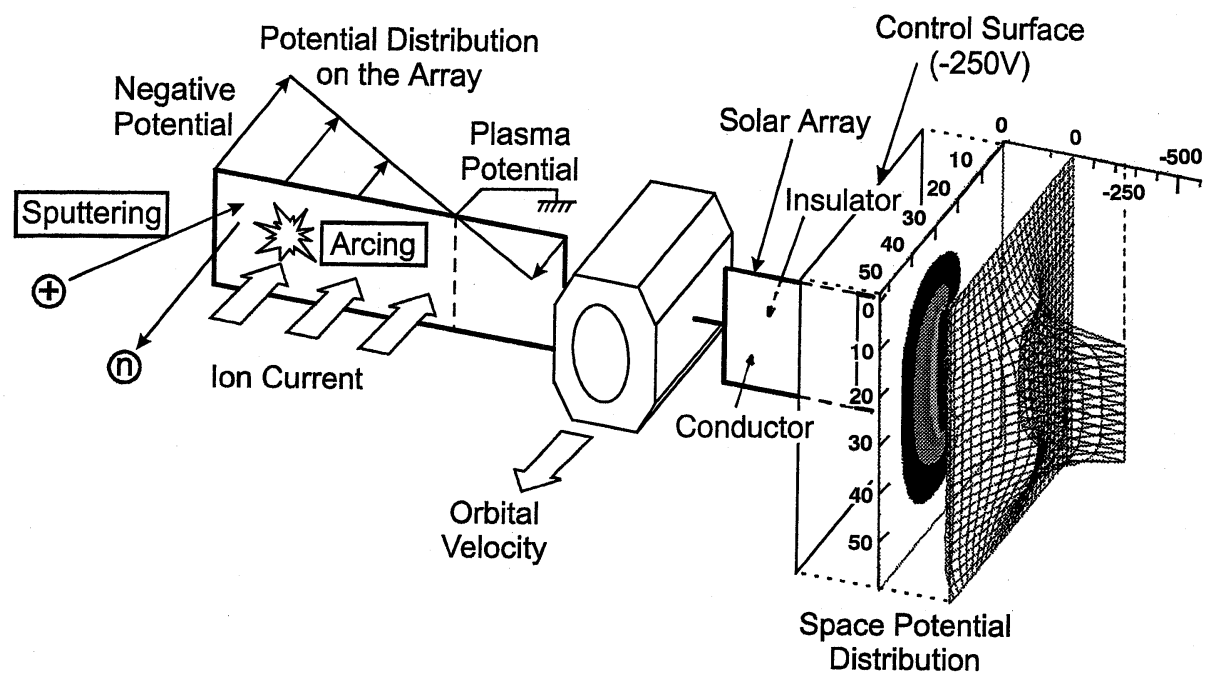

Fig. 1 Interactions of high voltage solar panel with ionospheric plasma and calculated space potential distribution under applied voltage of $-250 \mathrm{~V}$. Mesh numbers of $0-50$, in which an interval between meshes corresponds to $50 \mathrm{~mm}$ in the real interval, are used in the right side solar panel.

$$
N_{e}=N_{0} \exp \left(\frac{e V}{k T_{e}}\right)
$$

ここで, $e$ は電気素量, $\varepsilon$ は真空誘電率, $k$ はボルツマン 定数, $N_{0}$ は中性プラズマ数密度, $N_{\mathrm{i}}$ はイオン数密度, $N_{\mathrm{e}}$ は電子数密度, $V$ は電位, $T_{\mathrm{e}}$ は電子温度, $M$ はイオ ン分子質量, $v$ はイオン速度, $t$ は時間である. 計算方 法として Particle-In-cell (PIC) 法を用い, その境界条件 としてパネル導電面に一定の電位を与え, パネルの絶縁 面と計算領域の外周の電位を零とした. 実際のパネル上 の電位はFig. 1 左図のよ5に一定とはならず太陽電池 素子の接続状態と人工衛星本体の電位分布に依存した， ある分布を持つはずであるが，本解析では簡単化のため に一様分布を仮定した．繰り返し計算は電場の空間分布 がほぼ定常状態になったとき止め解を求めた。

\section{3. 計算結果と検討}

導電面の電位がー $1 \mathrm{kV}$ のソーラーパネルがプラズマ 流中に平行に置かれた時の空間電位分布を Fig. 2, イオ ン電荷の密度分布を Fig. 3 にそれぞれ示す.また Fig. 1 の右図にプラズマ流に垂直に対面したー $250 \mathrm{~V}$ のソー ラーパネル周りの電位分布を示す．但し，これらの図中 では長さの単位として計算メッシュ $(50 \times 50)$ を直接使 用して扣り，1メッシュ間隔は50 mm に相当する. ソー ラーパネルの幅 $1 \mathrm{~m}$ は20メッシュになる.

計算結果からイオンシースが十分に計算領域内で収束 していることがわかる. 高電圧ソーラーパネルの周りに 形成されたイオンシースは導電面側に大きく広がり,

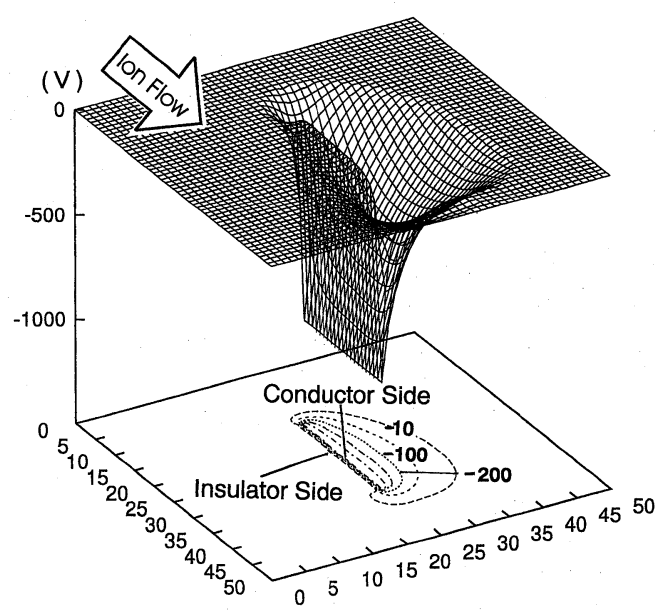

Fig. 2 Calculated space potential distribution around solar panel under $-1 \mathrm{kV}$. Equipotential lines of $-10,-100$ and $-200 \mathrm{~V}$ are drawn. Mesh numbers of $0-50$, in which an interval between meshes corresponds to $50 \mathrm{~mm}$ in the real interval, are used.

Fig. 2, Fig. 3 のよらにパネルが流れに平行に飛行する 場合はシースが流され下流域で厚くなる.さらに, イオ ンシースは導電面のみならず絶縁面側にも形成されるこ とがわかる. Fig. 3 のイオン電荷の密度分布はこれらシ 一ス形状とよく対応している. プラズマ流に平行に置か れたソーラーパネル周りのイオンはFig. 4 に示すよ5 に，そのシースが十分広がっているのでかなり遠方から 


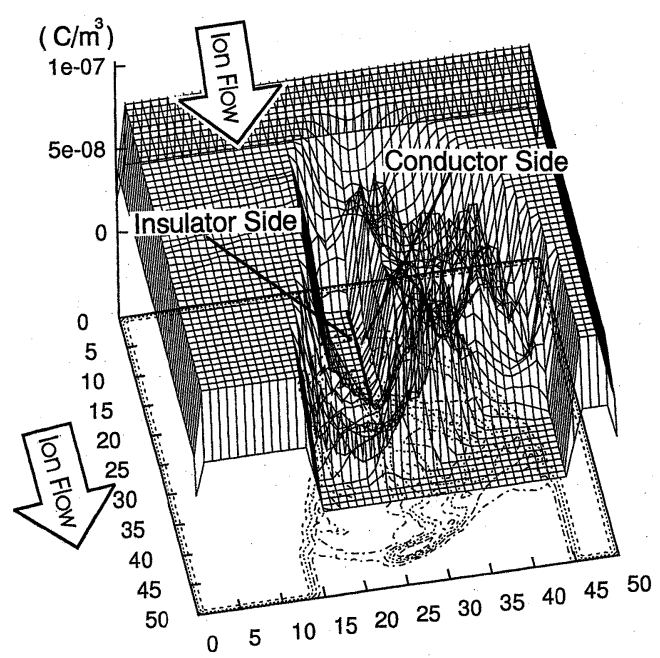

Fig. 3 Calculated positive charge density distribution around solar panel under $-1 \mathrm{kV}$. Mesh numbers of $0-50$, in which an interval between meshes corresponds to $50 \mathrm{~mm}$ in the real interval, are used.

軌道を曲げられソーラーパネルに衝突する. 特に, 絶縁 面側を通過するイオンも導電面側に回り込みパネルに衝 突するのでそれに起因する化学スパッタリングによる表 面材料の劣化には十分注意する必要がある.

\section{4. まと め}

本研究では, LEO 上の宇宙飛翔体の高電圧ソーラー パネルと電離層プラズマとの干渉現象を明らかにするた めに, PIC 法による 3 次元プラズマ粒子シミュレーショ ンが行われた.ソーラーパネル周りのイオンシースの形 状, 挙動が明らかにされ, 高速イオンの衝突による材料 劣化特性,イオンドラッグなどを具体的に見積もること が可能になると期待される.

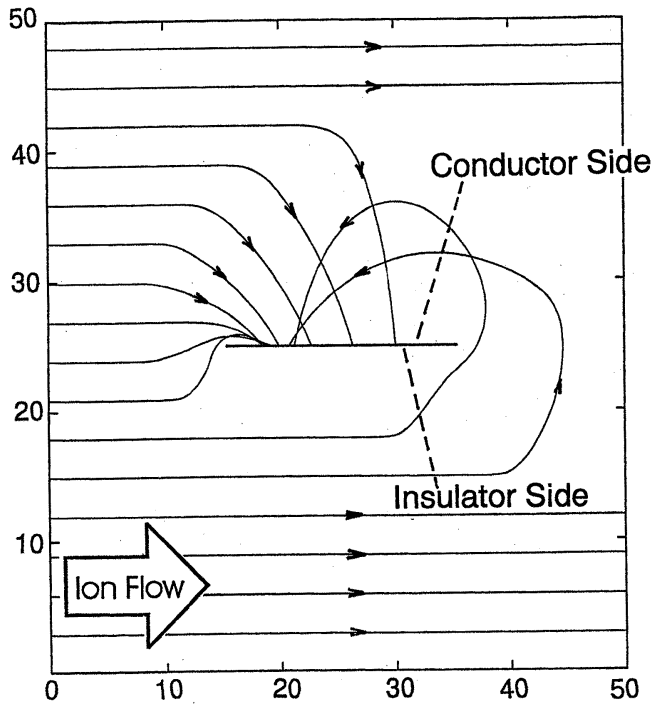

Fig. 4 Calculated trajectory of ions around solar panel under $-1 \mathrm{kV}$. Ions with $7.6 \mathrm{~km} / \mathrm{s}$ move from the left side toward the right one. Mesh numbers of $0-50$, in which an interval between meshes corresponds to $50 \mathrm{~mm}$ in the real interval, are used.

\section{〔文献〕}

1) H. Tahara, L. Zhang, M. Hiramatsu, T. Yasui, T. Yoshikawa, Y. Setsuhara and S. Miyake: J. Appl. Phys., 78 (1995) 3719.

2) 田原弘一, 張 麓璐, 平松美樹, 安井利明, 吉川孝 雄 : 日本航空宇宙学会誌, 43 (1995) 170.

3）田原弘一, 張 麓璐. 平松美樹, 安井利明, 吉川孝 雄 : 真空, 38 (1995) 391.

4) H. Tahara, A. Ogo, L. Zhang, T. Yasui and T. Yoshikawa: 20th Int. Symp. on Space Technol. and Science, Gifu, ISTS-96-b-38p, 1996.

5) 田原弘一, 小河 敦, 張 麓璐, 安井利明, 吉川孝 雄 : 日本航空宇宙学会誌, 1997, 印刷中. 